\title{
A Study on Green Economy Indicators and Modeling: Russian Context
}

\author{
Natalia Vukovic ${ }^{1, *}\left(\mathbb{D}\right.$, Vladimir Pobedinsky ${ }^{2}{ }^{\oplus}$, Sergey Mityagin ${ }^{3}$, Andrei Drozhzhin ${ }^{3}$ and \\ Zhanna Mingaleva 4 (D) \\ Graduate School of Economics and Management, Ural Federal University, Yekaterinburg 620002, Russia \\ 2 Automobile and Transport Institute, Ural State Forest Engineering University, Yekaterinburg 622100, Russia \\ 3 Director of Institute of Design \& Urban Studies, ITMO University, Saint-Petersburg 197101, Russia \\ 4 Department of Economics and Industrial Production Management, Perm National Research Polytechnic \\ University, Perm 614990, Russia \\ * Correspondence: shpak17121978@gmail.com
}

Received: 4 July 2019; Accepted: 29 July 2019; Published: 26 August 2019

check for updates

\begin{abstract}
This article aims to assess and forecast the dynamics of a regional green economy. The research relevance is determined by the need to develop theoretical and methodological basis of the green economy for the transition period and to identify criteria basis for assessing the state and regional level of it. The authors applied the modern methods, which allowed to model criteria considering data uncertainty and both static and dynamic criteria. The research process involved the methods of scientific analysis, comparison and synthesis, the theory of fuzzy sets, and fuzzy modeling. The main principles and methodology of the criteria evaluation for a regional green economy are proposed. The principal methodological approach in this research combines the current state and dynamics of the green economy in evaluating and forecasting the conditions of data uncertainty. The research results form a theoretical, methodological, and practical basis for assessing the current state and level of a regional green economy development, determining the effectiveness of environmental and economic programs, optimizing financial management, conducting environmental monitoring, and developing state plans.
\end{abstract}

Keywords: green economy; green economy assessing; criteria for green economy assessing; visual-block modeling; fuzzy modeling

\section{Introduction}

Currently, the aggravation of global environmental problems has jeopardized the existence of human civilization and have intensified the search for new ways for further development of the world economy. Such a situation is caused by the so-called "Decapling Effect" [1], when natural resources are declining, and human consumption is increasing. To solve this problem, the world community adopted the concept of the green economy, which today has become not just an opportunity, but an indispensable way of all the developing countries to ensure the safe future of their citizens [2].

The transition to the green economy has become central in the UN conference in Rio de Janeiro in 2012, where the final document indicates that each country can determine the transition to the green economy in accordance with its national plans, strategies, and priorities for sustainable development.

The state policy in terms of the green economy is aimed at protecting the environment and protecting the interests of the society. The essential elements are environmental audit, environmental certification and other activities.

For process management of the green economy, it is very important to use a combination of assessment and actual data. However, the existing tools do not allow to compare technologies with 
each other or give a quantitative assessment of the projects for environmental performance indicators. Moreover, they cannot be optimized. Traditional methods were designed for supervisory purposes, and therefore, act as restrictions for legal and regulatory incentives for the green economy development.

The transition to green economy demands the creation of a theoretical and methodological basis and a system of evaluation indicators. They are necessary to monitor the transition process and to mark management actions taking into account the uncertainty conditions and dividing criteria by their nature as static and dynamic.

The main part of theoretical modern research recommends a big list of criteria, but this number cannot guarantee the efficiency of the assessment because of practice. It is not possible to collect the actual data like we can see in Russia, which accept National pathways to the Sustainable Development Goals (SDGs), but on the official website of Russian Government Statistics (http://www.gks.ru/wps/wcm/ connect/rosstat_main/rosstat/ru/statistics/goalOfDevelopment/) all 17 criteria are still not presented. It should be noted that many works by scientists like Pearce, Markandya, Barbier (1989); Zakharova (2011); Tereshina, Degtyaryova (2012); Bochko, Nekrasov, Pakhomova, Rikhter, Malyshkov (2014); Samarina, Rodionova, Lipina (2015); Mauritzen (2016); Zorpas, Lasaridi, Pociovalisteanu, Loizia (2018); $\mathrm{Wu}, \mathrm{Yu}, \mathrm{Li}$, Huang (2018); Sun, Zhang, Zhang, Niu (2018); Lyytimäki, Antikainen, Hokkanen, Koskela, Kurppa, Känkänen, Seppälä (2018); Vukovic (2018) [3-15], are characterized by completely abstract approaches and the same uncertain results. Most of these works develop basic concepts, definitions, criteria for future research, but research directions are not specified, therefore, the purpose of the proposed criteria is unclear. It is possible to note the materials of various forums of the national government, where the criteria assessments are more specifically outlined, but the official documents contain no methodological approaches to the problem. In all mentioned research, authors recommend using static criteria and they do not divide green economy criteria into dynamic and static groups.

As the research object, the green economy belongs to the class of large systems, therefore, it should be studied from this position. Nevertheless, scientists ignore this approach, by judging the green economy by reviewing publications. As a result, most authors single out only a prominent part of the research object, and it appears in a generalized form, claiming to describe the entire object in all its diversity. Theoretical approaches are similar when several groups of ecological and economic indicators are considered.

It is also important to notice that the green economy in terms of the classical theory is a multidisciplinary field, which consists of socio, eco, and economy elements, the balance of which makes an economy sustainable. Karl Burkart defines the green economy based on the six main sectors [16] including:

- Renewable energy;

- Green buildings;

- Sustainable transport;

- Water management;

- Waste management;

- Land management.

Therefore, the criteria for the green economy assessment should include minimum one criterion for each element of the green economy which is part of sustainable development.

There exist some contradictions and conflicts between the results obtained by researchers, different classifications, and various lists of criteria because of the breadth of interpretation and the vagueness of basic concepts.

In the initial stages of the research of a complex system, which the green economy relates to, methodological problems do not arise. However, if problems of forecasting the conditions and behavior of the system are solved, as it is almost always in the case of modeling, the role of criteria becomes crucial. In this case, the criteria should be strictly defined by the system parameters, and not by the "indicators", "factors", coefficients of different "capacity", "latitude", and other abstract concepts. 
This situation does not provide a basis for further theoretical studies using modern modeling methods, which is a serious obstacle for the assessment and development of the socio-ecological and economic state of the region from the point of view of the green economy.

Thus, rethinking of the concept of the green economy, developing a research methodology in this area, the evaluation of the criteria system, applying modern modeling methods with factors of uncertainty predetermined the purpose of this work.

The purpose of the research, some results of which are presented in this article, is substantiating the main provisions and first-priority tasks for the green economy as a new scientific direction and in developing a list of criteria to assess the green economy by modern modeling systems, taking into account the uncertain conditions.

\section{Literature Review}

The research is based on the methodology of Rudneva, Gurieva [17], Pinaev, Ledascheva [18], Uskova [19] who used an integrated indicator value for the assessment of greening economy and linguistic variable criteria in the conditions of data uncertainty (Table 1).

Considering the issue of assessing the current level of the green economy development in the region, one can turn to the methodology of Rudneva, Gurieva [17]. They offer the system of indicative assessment of the level and degree of the region ecology and the economy. The system includes five groups of indicators of greening.

The green economy of the region is an ecological-economic system. From this perspective, the questions of the green economy development and strategic environmental assessment were considered by Pinaev, Ledascheva [18].

Uskova [19] offers a classification of the green economy indicators. She attempts to specify the criteria and to assign the dimensions, presenting them in percentages or fractions. Another Uskova's list offers to assess the forecast for the development of the green economy on a national scale.

According to the Rudneva, Gurieva research [17], the level of greening is an integrated quantitative indicator that characterizes the qualitative development of the greening process. In the results, presented by these authors, the value is represented by some recommended requirements for indicators. Moreover, the value ranks and normalizes the indicators; using integrated formulas for the calculation of indicators are used.

Interestingly, for the development of economic indicators the authors used the key position of the mathematical theory of fuzzy sets [20]. So, the degree of the economy greening is estimated by indicators that are described by the term sets of the linguistic variable. This description is given in Table 1 , which is a fragment of the table from the work mentioned.

Table 1. The degree of the economy greening.

\begin{tabular}{ccccccc}
\hline Name/Degree & 0 Degree & 1 Degree & 2 Degree & 3 Degree & 4 Degree & 5 Degree \\
\hline Name of the degree & "Zero" & “Initial" & "Basic" & "Medium" & "High" & "Progressive" \\
\hline \multicolumn{7}{c}{ Integrated indicator value } \\
\hline Economic indicators & {$[0-0.15]$} & {$[0.16-0.3]$} & {$[0.31-0.46]$} & {$[0.47-0.62]$} & {$[0.63-0.78]$} & {$[0.79-1]$} \\
\hline
\end{tabular}

The fragments of the analysis performed on the review of known studies allowed making the following conclusions:

- General model of the green economy is not defined; therefore, methodological problems may arise at any stage of further research and the implementation of these results into practice;

- All the green economy indicators estimated have the properties of uncertainty, fuzziness, therefore, many authors involuntarily used the elements of the theory of fuzzy sets to describe the object of research; for example, the data in Table 1 are presented in the form of linguistic variables and 
in the future, it is necessary to develop such an approach for making decisions in conditions of uncertainty;

- Developing criteria for assessing the green economy, researchers do not strictly outline defined rules or principles for their formation;

- Authors do not clearly set goals, do not investigate the purpose of the indicators proposed, therefore, there are no corresponding recommendations for the further usage of these criteria.

\section{Materials and Methods}

Methods of scientific analysis, comparison, and synthesis were used in the research process. We have analyzed and compared the methods applied to basic criteria assessments for socio-ecological and economic approaches to the green economy development. This allowed us to identify the main trends in the justification of various indicators.

We used the approach adapted from Maslow's pyramid [21] for the green economy assessment by Finkbeiner, Schau, Lehmann, Traverso [22], which they implement in the research of life cycle sustainability assessment, and we apply the same approach for the green economy assessment (Figure 1).

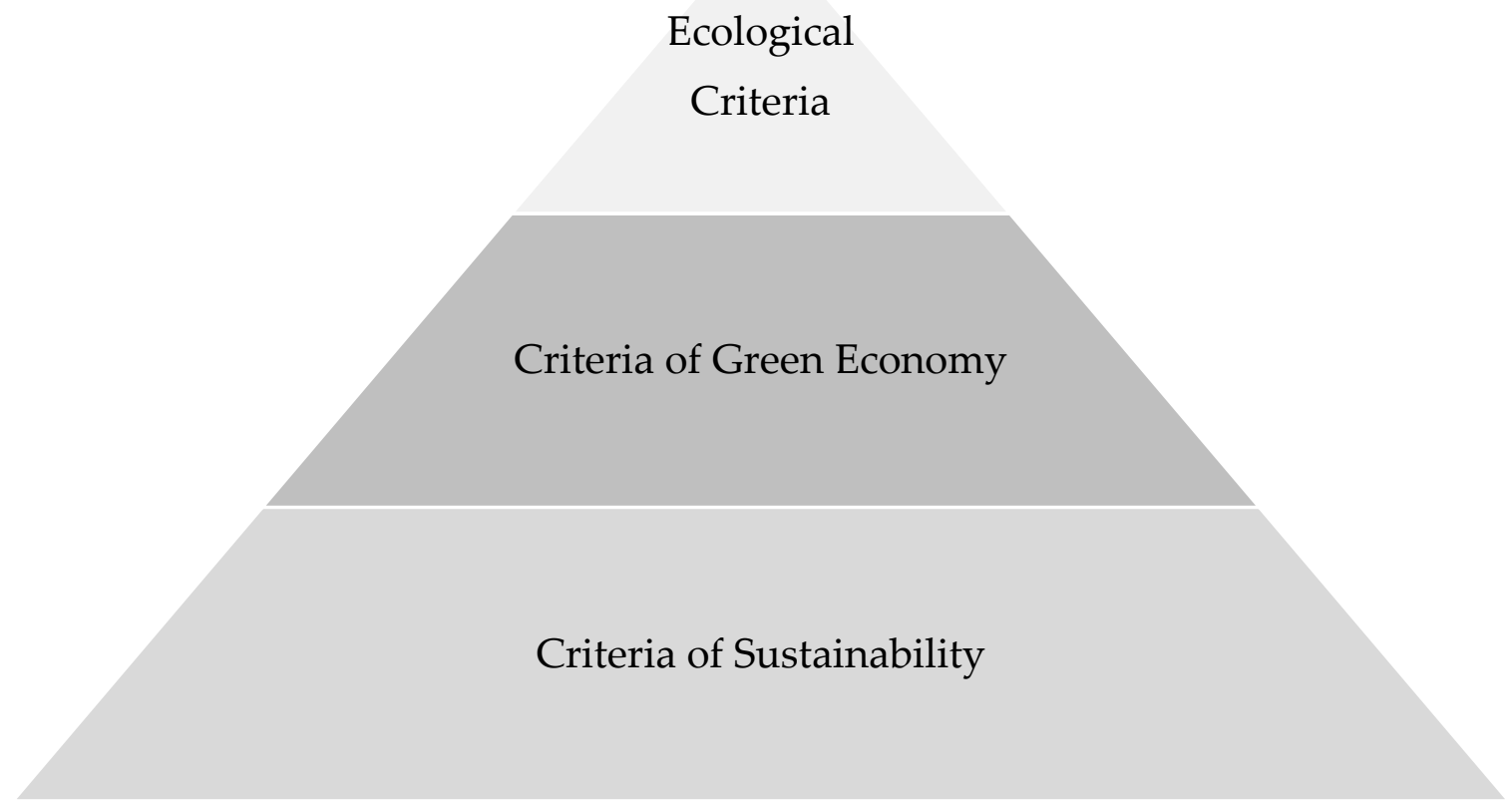

Figure 1. Adaptation of Maslow's pyramid [20] for green economy assessment approaches.

Excessive detailing leads to duplication of indicators, as they are often interrelated. In addition, general specific methods of forming criteria and other features are defined from the comparative analysis.

The most important methodological approach in these studies was the initial orientation toward the practical application of the criteria developed for forecasts, both the current state and the dynamics of the green economy development. As known, simulation modeling is now recognized as the general methodological research. Among the systems applied for simulation in these studies, we focus on the system of visual-block modeling and one of its concepts, namely, system dynamics.

A regional green economy system is hierarchical in terms of the components significance or subsystems. Consider subsystems in the hierarchical order (Figure 2).

The general methodology is consolidated, and the primary research tasks are shown in Figure 2.

In this article, the emphasis is on developing a structural diagram of the research object as a green economy system; the development of a methodological approach to the formation of a system 
for assessing the green economy; justification of the criteria list for assessing the green economy and developing recommendations for their further use in modern simulation systems considering the uncertainty conditions.

\subsection{First Level Subsystem}

It is obvious that the green economy system is manageable. The key role of management was proven by Yang, Zhang, Jiang, Sun [23]. The regulatory framework is only one mechanism for the governance on a national scale explained by Pociovălișteanu, D. M., Novo-Corti, I., Aceleanu, M. I., Șerban, A. C., Grecu, E., Duwe. S., [24,25]. However, the regulatory and legal framework determines only the strategic tasks, such as federal laws, decrees, government regulations, in simple terms, it only defines "what to do". Hence, the implementation of strategic tasks or "how to do" is conducted according to the regulatory and technical bases. These both bases are characterized by how well they are developed in the part of the green economy, i.e., quantitatively; it can be estimated by the number of regulatory legal documents in the area. The dynamics of this subsystem development can be traced to a change (increase or update) in the number of relevant documents.

If the regulatory framework is the management mechanism, then the financing mechanism is the driving force. In addition to budget financing and various investments, a significant role belongs to the taxation system, acting in many cases similarly to the financing one. Funding volumes for each subsystem is an indicator of the current state of the "financing" element, and a change in volume characterizes the process dynamics as shown by Jin, Han [26] and Monasterolo, Raberto [27]. Fiscal stimulation of green industries is also very important, and many scientists argue about this fact; Dulal, Dulal, Yadav, Durdyev, Zavadskas, Thurnell, Banaitis, Ihtiyar [28,29].

Thus, the first level subsystem "management" consists of the following elements "regulatory base", "normative and technical base", and "financing". It should be noted that all the three elements are also subsystems and depend on the details, they can be considered as complex systems.

\subsection{Second Level Subsystem}

It includes the highest priority areas for the contribution to the economy of green growth or system-forming elements. Each system-forming area has a key indicator, which is characterized by both the current state (static) and the indicator of its change (dynamic). For energy, the main sign from the green growth point of view is to determine energy intensity Golubetskaya [30], Porfiriev [31], Andreas, Burns, Touza [32], Kang, Li, Qu [33], and in this interpretation it should be considered with renewable and non-renewable sources. Similarly, in "transport" subsystem, detailing the indicators and focusing on the electric and other more ecological drive are not necessary, as the most important indicator is not actually the transition to a new drive, but the emissions and waste from technical operation. At the same time, the amount of emissions can be simultaneously an indicator for the volumes of hydrocarbon fuel usage.

\subsection{Third Level Subsystem}

It includes construction. Many authors suggest considering production of materials and the introduction of ecological housing. However, in this part, you only need to consider the effects of the objects being erected, and the construction materials that the industry refers to production. In addition, the number of energy-efficient and "smart" houses should be included in another group "ecology of dwelling". The role of modern eco-infrastructure in urban zones and green cities is reportedly enormous in this field, Newton [34]. The role of business in greening the economy and sharing of green industries is also remarkable in a regional economy presented by Baranova, Paterson [35] and Chen, Lan, Gao, Sun [36]; and the green economy is to be assessed according to specific indicators. The remaining subsystems of the third level are related to natural resources. 


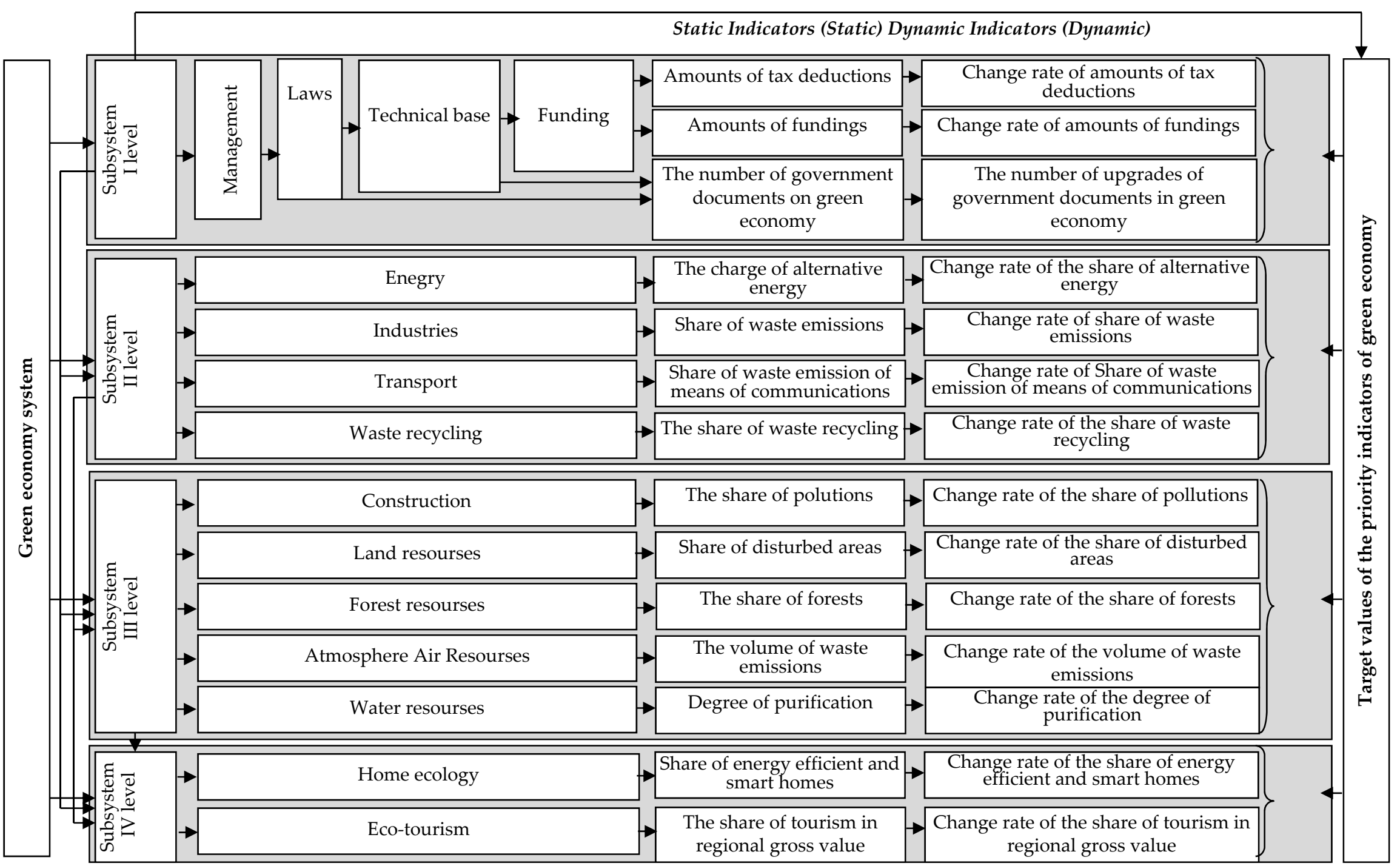

Figure 2. The system of criteria for a regional green economy (static and dynamic). 


\subsection{Fourth Level Subsystem}

Element "ecology of dwelling", on the one hand, can be pointed as one of the targets and the desired result of the new economic conditions. "Ecology of dwelling" depends on many factors. The ecological parameters of the dwelling are a consequence of the other subsystem functioning; therefore, it is assigned to the last level of the subsystems. At the same level, the element "ecological tourism" includes not only secondary parameters, for example, the number of ecological routes or tourists, Stroebel [37], but in this case the most important indicator is financial revenues to the regional budget from eco-tourism.

The green economy implementation should ensure an inexhaustible consumption of resources while maintaining the attained level of human welfare. Hence, the final indicators follow logically. For example, the indicator "three zeros" for energy-efficient houses, values close to "zero" and other criteria in terms of consumption of resources or waste should be justified.

For the group of criteria of each level, an integral indicator is formed, and its quantitative value should be further justified for a stage of the green economy development. Currently, zero indicators in terms of waste and consumption of resources are unattainable, so their values are likely to be different at specific stages and are justified from an economic standpoint. One of the ways to justify can be optimization according to the criteria for minimizing these indicators. Since the problem is multi-criterion, it is advisable to formulate a generalized indicator of efficiency using weight coefficients for the criteria.

The main conclusions of the analysis of existing studies on the green economy show that the bulk of publications is devoted to the research of the green economy criteria assessments. The review reveals a significant discrepancy in the approaches to the formation of these criteria.

Authors tend to consider a separate aspect of the problem and try to build a system of criteria, which they assume should be comprehensive. However, everyone intuitively understands that the object of research is complex, multifaceted, and then many indicators are offered to consider various properties of the study object. It is also clear that the concept of the green economy has different aspects of semantic content, so it is advisable to aggregate criteria.

For example, the structure of greening indicators includes five groups and each group includes different indicators. However, here the authors do not notice the fundamentally important point that these groups may not be equivalent. This property is noted, and the authors propose to rank the criteria for practical application. In other works, there is an attempt to more precisely specify the criteria, and to make some standardization, and instead of assigning dimensions, to present the criteria in percentage terms or fractions.

Since the criteria describe a multi-faceted concept, many of them is required. This leads to the complexity of the evaluation, therefore, offers integrated quantitative indicators presented by Nahman, Mahumani, De Lange [38].

Almost all the estimates of the green economy have the properties of uncertainty, fuzziness, so many authors involuntarily use elements of the theory of fuzzy sets, Zadeh [20], to describe the object of research, but they do not further develop these questions.

The lack of a systematic approach to the consideration of the green economy and development of criteria for assessing, researchers do not fully observe the patterns of the structure, the interrelationship of interaction, and insufficiently consider their properties. At the same time, without having a special methodology for the formation of criteria, they do not outline strictly defined rules and principles for this. Thus, the main reason for the impossibility of creating a scientifically based system of criteria assessment of the green economy is the lack of an appropriate methodology.

Foreign studies quite convincingly reveal the depth of the problem. The above fragments of the analysis performed on the studies enable to draw the following conclusions:

- A general model of the green economy is not defined; therefore, methodological problems can arise at any stage of further research and the introduction of results into practice; 
- The green economy has the properties of uncertainty, fuzziness, therefore, many authors involuntarily use the elements of the theory of fuzzy sets in the description of the research object, so in the future it seems promising to develop such an approach for making decisions under uncertainty;

- Developing criteria for assessing the green economy, researchers do not outline strictly defined rules or principles for their formation;

- Current stage of the green economy development, the authors do not set clearly defined goals, do not study the purpose of the indicators proposed, therefore, there are no appropriate recommendations for further use of these criteria.

\section{Results}

\subsection{Development of Methodology for Formation of Criteria for Green Economy}

The methodology for justifying the list of criteria has been developed considering the proposed structural scheme, well-known positive experience in creating systems to assess the green economy, and identified shortcomings in the proposed classifications.

1. The object of research is a complex system of the green economy; hence, the development of a criteria evaluation should proceed from a systemic approach and represent the object in the interconnection of constituent parts.

2. It is necessary to consider the unevenness of the criteria, their different contribution to the investigated property; therefore, if they form a system of indicators, it is necessary to consider this system as a hierarchical structure.

3. The hierarchy of indicators should be constructed considering the significance of the criteria and classification characteristics.

4. Assessment of the current state of the green economy in the region should use static indicators, similar, for example, to those used in physics, like mass, volume, etc.

5. To forecast the green economy development in the region, it is convenient to use dynamic indicators, i.e., time-dependent parameters. Physically, they determine the rate of the change of a certain parameter.

6. The criteria should be as informative as possible and reflect the most significant property, while the specific indicators have much more informative value.

7. It is advisable to rank the criteria by significance, according to the contribution to the forecasted value, especially in cases when the tasks of optimization are solved. For example, emissions of production are not comparable with the number of ecological tourist routes or "ecological literacy", the criteria that are offered by some authors.

8. Criteria should not be interdependent, so as not to duplicate each other and exclude redundancy of indicators.

9. An integral indicator can be used to characterize the element of the green economy model, which meets several criteria.

10. The basic principle of grouping criteria within a type is the closeness of criteria to the ecological principle.

11. The data used to determine the criterion should be publicly available.

12. For practical use of the criteria when comparing, modeling, performing calculations, forming integral criteria, they should be presented in a standardized form, for example, by formula

$$
K n=(K \max -K) /(K \max -K \min )
$$

where

$\mathbf{K} \mathbf{n}$ - the normalized value of the criterion;

Kmax-the maximum value of the criterion; 
Kmin - the minimum value of the criterion;

$\mathrm{K}$ - the current value of the criterion.

13. When forming integral criteria from a hierarchical list or generalized criteria in optimization problems, in addition to normalization, it is preferable to use them with weighting coefficients.

\subsection{Development of a System of Criteria for Assessing the Green Economy}

We have developed a list of criteria to forecast the green economy development on a regional scale based on the methodology principles formulated, hierarchical structural scheme of elements, properties and indicators. The list is divided into types, levels of significance and can be used either for assessing the current state of each subsystem, or for forecasting the development of a regional green economy (Table 2).

Table 2. List of criteria for a green economy assessment.

\begin{tabular}{|c|c|c|}
\hline $\begin{array}{l}\text { Regional Green } \\
\text { EconomyElement }\end{array}$ & Criteria & Measurement \\
\hline \multicolumn{3}{|c|}{ First Level Criteria } \\
\hline 1.The legal regulation & $\begin{array}{l}\text { Number of documents for the green } \\
\text { economy, units }\end{array}$ & $\begin{array}{l}\text { Change in quantity } \\
\text { documents, units per year }\end{array}$ \\
\hline 2.Taxation & $\begin{array}{l}\text { Income from taxes, } \\
\text { million rubles. /GRP }\end{array}$ & $\begin{array}{l}\text { Change in income from taxes, } \% \\
\text { per year }\end{array}$ \\
\hline 3. Financing & Amount, mln. rub. /GRP & Amount change, $\%$ per year \\
\hline \multicolumn{3}{|c|}{ Second Level Criteria } \\
\hline 4.Power engineering & Share from renewable sources, $\%$ & $\begin{array}{l}\text { Change in the share from } \\
\text { renewable sources, \% per year }\end{array}$ \\
\hline 5.Production & Index of wastelessness, $\%$ & $\begin{array}{l}\text { Changing in the index of } \\
\text { wastelessness, \% per year }\end{array}$ \\
\hline 6.Transport & $\begin{array}{l}\text { The share of emissions, } \\
\text { thousand tons } / \text { kWh }\end{array}$ & $\begin{array}{c}\text { Change in the share of emissions, } \\
\% \text { per year }\end{array}$ \\
\hline 7.Recycling & Share of waste recycling, $\%$ & $\begin{array}{l}\text { Change in the share of waste } \\
\text { recycling, \% per year }\end{array}$ \\
\hline \multicolumn{3}{|c|}{ Third Level Criteria } \\
\hline 8.Building & The share of pollution, $\%$ & $\begin{array}{c}\text { Change in the share of pollution, } \\
\% \text { per year }\end{array}$ \\
\hline 9.Land resources & Share of disturbed areas, $\%$ & $\begin{array}{l}\text { Change in the share of disturbed } \\
\text { areas, \% per year }\end{array}$ \\
\hline 10.Forest resources & Share of forest fund, $\%$ & $\begin{array}{c}\text { Change in share of forest fund, } \% \\
\text { per year }\end{array}$ \\
\hline 11.Water resources & Purification volumes, \% & Change in purification volumes, $\%$ \\
\hline 12.Atmospheric air & $\begin{array}{l}\text { Quantity of emissions, } \\
\text { thousand tons per year/GRP }\end{array}$ & $\begin{array}{c}\text { Change in quantity of emissions, } \\
\% \text { per year }\end{array}$ \\
\hline \multicolumn{3}{|c|}{ Fourth Level Criteria } \\
\hline 13.Ecology of the dwelling & Share of energy-efficient housing stock, $\%$ & $\begin{array}{c}\text { Change in share of energy-efficient } \\
\text { housing stock, \% per year }\end{array}$ \\
\hline 14.Ecological tourism & Share in the budget from eco-tourism, $\%$ & $\begin{array}{l}\text { Change in share in the budget } \\
\text { from eco-tourism, \%\% per year }\end{array}$ \\
\hline \multicolumn{3}{|c|}{ Fifth Level Criteria } \\
\hline 15-18. Subsystems of I-IV levels & Integral criteria of subsystems of I-IV levels & $\begin{array}{l}\text { Change of criteria of subsystems } \\
\text { of I-IV levels, \% per year }\end{array}$ \\
\hline $\begin{array}{l}\text { 19. The generalized efficiency } \\
\text { index (GEI) }\end{array}$ & $\mathrm{GEI}=\Sigma \mathrm{K}_{\mathrm{Bi}} \mathrm{K}_{3 э \mathrm{i}} *$ & Change in GEI, \% \% per year \\
\hline
\end{tabular}

$\mathrm{K}_{\mathrm{Bi}}$ - $\mathrm{i}$ - weight coefficient; Kzei-the $\mathrm{i}$ criterion of the green economy is normalized. 
Integral criteria of subsystems of levels I-IV are used to evaluate the components of the green economy, and a general efficiency indicator is intended for the whole system. Weight coefficients before criteria are assigned when optimizing system parameters, for example, legal or financial management of the system and other parameters.

A significant difference between the proposed list and the known criteria is the presence of the first three elements that assess the subsystem of management of the system "green economy". It is necessary to consider these indicators in detail.

The phrase "... for the purpose of effective management ..." explained by Uskova [19] is key in many works on economics, and it shows the main goal of economic science. On the one hand, it is obvious that not only green but also any economy should be a managed system. On the other hand, in the known works on the criteria assessment of the green economy, there are no criteria that assess this system from the management point of view. Consequently, in these cases, the green economy system is regarded as unmanageable.

Public administration has only two instruments: regulatory and legal, and financial management.

Financial management can be quantitatively estimated by the amount of financing and taxation policy.

The mechanism of normative-legal management is complicated and, strictly speaking, it is extremely difficult to give such an assessment. Moreover, comparative assessments can serve as the number or share of documents regulating the area of the green economy from the total volume of the regulatory and legal framework. At the same time, the share of documents that regulate the region of the "green" economy from the total volume of the regulatory and legal framework is a characteristic of the base itself, which considers its development from the point of view of the green economy.

While the number of documents shows how well the system management issues have been developed, this characterizes the level of development of the direction of the green economy. Thus, the dimensions of the criteria related to management are as follows. For the condition criterion, it may be taken "number of documents regulating the green economy" units, and for the development criterion there is "change in the number of documents", units/year.

\section{Discussions}

In accordance with the goal of the research, the following results have been obtained:

- The main tasks for a new scientific direction for the transition period of creating the green economy have been formed;

- The definition of the concept of the "green" economy is formulated, which considers the goal and the main tools for achieving it;

- The model of the green economy has been developed, unlike previous similar studies, it is hierarchical with isolated system-forming elements, with a clearly defined control element;

- The list of criteria for the green economy is developed;

- Recommendations have been developed for the application of the green economy criteria in the Simulink simulation system, considering uncertainty conditions.

If we generalize the results on the whole, then we can say that, in accordance with the list developed, the primary tasks for the transition and development of the green economy have been solved.

Scope of the application criteria. The scope of the criteria list proposed covers two main areas: in practice and in scientific research.

In practice, evaluation criteria are used in the methodology for forecasting the level of the green economy development. It is necessary to develop plans and government programs with an environmental assessment of the planned activities impact on the environment in accordance with the national legislation. Similar actions are performed for programs developed for several industries: energy, industry, forestry, agriculture, fisheries, transport, urban and rural development planning, land use, and many others. 
The forecasting method allows at the initial stage of the program implementation to estimate:

- The relevance of the plan, primarily to promote sustainable development and considering the impact on public health;

- $\quad$ Risks for the environment and for public health;

- Influence on other plans and programs;

- Quantify statistically the magnitude of environmental impacts and the impact on the health of the population from the implementation of programs (e.g., the magnitude of the geographical area of impact or the number of people involved);

- The impact of the program on other projects and areas of activity in terms of funding;

- Influence on strategic or vulnerable areas, nature protection zones that have a recognized protected status.

In research and development activities, the criteria are also likely to find a wide application. The nearest future topics to study are the formation of a generalized indicator of the green economy effectiveness for the task of optimizing the main parameters. Another promising direction for further research has already been identified above. It is an imitation modeling of the green economy processes, considering the conditions of uncertainty, though the range of tasks to be solved will be virtually unlimited.

The proposed methodology of regional green economy assessment can be used by regional or federal government in budgeting process and strategy planning process for the following needs:

- Evaluation of environmental and economic programs by green economy criteria;

- Optimizing financial policy for stimulation of the green economy;

- $\quad$ Environmental monitoring because of the green economy development;

- Developing state plans because of the green economy.

\section{Conclusions}

Summarizing the results of the analysis of well-known publications, the proposed general methodology and structural scheme of the methodology for developing criteria assessments and the list of criteria and recommendations for modeling criteria can be the following:

1. The development of the green economy is a worldwide trend and the attention of many Russian and foreign researchers are increasingly devoted to this problem. The development of this direction should be the creation of theoretical bases and mathematical models for the functioning of regional, socio-ecological, and economic systems based on the principles of the green economy, which is an urgent scientific problem aimed at solving global problems of mankind. The further development of the green economy requires fundamental research, which should be based on a systematic approach to the study of the problem. From this point of view, a general outline of the research methodology and priority tasks for the transition period, as well as the hierarchical structure of the study object of the green economy system, is subdivided into several system-forming component parts (Figure 2).

2. The principles of the formation of assessment systems for the green economy have been formulated, a methodology that considers the specific features of the object of study has been proposed. It allows to develop a list of evaluation criteria of the green economy with integral indicators for the components and a generalized indicator for the entire system.

3. The criteria proposed are sufficiently informative and available initial data, allow determining the current state and level of economic development accurately, and can be used in international comparisons of global economic development for evaluation procedures and optimization of parameters, for example, financial management of the green economy.

4. The complexity of the results, combined with the use of the latest achievements of mathematics, modern modeling methods, first imitative, fuzzy, allows us to consider uncertainty conditions 
and implement a fundamentally new approach to research the green economy based on the information technology.

Author Contributions: N.V. coordinated the work; data curation, Z.M.; formal analysis, N.V.; funding acquisition, S.M. and A.D.; methodology, V.P.

Funding: The research was funded by the grant of the Ministry of Education and Science of the Russian Federation to Perm National Research Polytechnic University \# 26.6884.2017/8.9 "Sustainable development of urban areas and the improvement of the human environment."

Conflicts of Interest: The authors declare no conflict of interest.

\section{References}

1. Anikina, I.D.; Anikin, A.A.; Nozhkina, N.A.H. Green economy as a condition of sustainable development of regions: Assessment of the effect of decoupling on the example of the Volgograd region in the collection: Alternatives to regional development. Conf. Proc. 2017, 1, 107-114.

2. Mishulina, S. Environmental safety in the Russian system of strategic goal-setting. Environ. Law 2017, 1, 39-43.

3. Pearce, D.; Markandya, A.; Barbier, E. Blueprint 1: For a Green Economy; Routledge: Abingdon-on-Thames, UK, 2013.

4. Zakharova, T.V. Zelenaia ekonomika kak novyi kurs razvitiia: global'nyi i regional'nyi aspekty (Green Economy as a New Course of Development: Global and Regional Aspects). Vestn Tomsk Gos. Univ. Ekon. 2011, 4, 28-38.

5. Tereshina, M.V.; Degtyaryova, I.N. Green growth and structural changes in the regional economy: Attempt of the theoretical and methodological analysis. Theor. Pract. Soc. Dev. 2012, 5, 123-129.

6. Bochko, V. Green economy: The second eternal problem of mankind. Bull. Ural Fed. Univ. Ser. Econ. Manag. 2014, 3, 113-119.

7. Bochko, V.S.; Nekrasov, A.A. Green economy: Theoretical approaches. J. Econ. Theory 2014, 1, 244-248.

8. Pakhomova, N.V.; Rikhter, K.K.; Malyshkov, G.B. Inklyuzivnyy ustoychivyy rost: Prioritety, indikatory, mezhdunarodnyy opyt, potentsial soglasovaniya s model'yu reindustrializatsii [Inclusive steady growth: Priorities, indicators, international experience, potential of coordination with reindustrialization model]. Probl. Sovrem. Ekon. 2014, 51, 15-24.

9. Samarina, V. Green economy of Russia: Some issues of theory and methodology. Natl. Interests Priorities Secur. 2015, 2, 2-9.

10. Rodionova, I.; Lipina, S. Green economy in Russia: Model and development forecast. Fundam. Res. 2015, 2, 5462-5466.

11. Zorpas, A.A.; Lasaridi, K.; Pociovalisteanu, D.M.; Loizia, P. Monitoring and evaluation of prevention activities regarding household organics waste from insular communities. J. Clean. Prod. 2018, 172, 3567-3577. [CrossRef]

12. Wu, H.; Yu, Y.; Li, S.; Huang, K. An Empirical Study of the Assessment of Green Development in Beijing, China: Considering Resource Depletion, Environmental Damage and Ecological Benefits Simultaneously. Sustainability 2018, 10, 719. [CrossRef]

13. Sun, Q.; Zhang, X.; Zhang, H.; Niu, H. Coordinated development of a coupled social economy and resource environment system: A case study in Henan Province, China. Environ. Dev. Sustain. 2018, 20, 1385-1404. [CrossRef]

14. Lyytimäki, J.; Antikainen, R.; Hokkanen, J.; Koskela, S.; Kurppa, S.; Känkänen, R.; Seppälä, J. Developing Key Indicators of Green Growth. Sustain. Dev. 2018, 26, 51-64. [CrossRef]

15. Vukovic, N. Green Economy: Definition and Contemporary Ecological-Economic Model. Bull. Ural Fed. Univ. Ser. Econ. Manag. 2018, 17, 128-145. [CrossRef]

16. Burkart, K. How do You Define the 'Green' Economy. MNN-Mother Nature Network. 2009. Available online: https:/www.mnn.com/green-tech/research-innovations/blogs/how-do-you-define-thegreen-economy (accessed on 18 April 2019).

17. Gurieva, M.A.; Rudneva, L.N. Evaluation of sustainable development of the region on the basis of the indicative assessment system level green economy. Her. UFU Ser. Econ. Manag. 2013, 3, 104-116. 
18. Pinaev, V.E.; Ledashcheva, T.N. Green economy development and strategic environmental assessment. Internet J. Sci. 2014, 1, 20.

19. Uskova, T. Management of Sustainable Development of the Region; LitRes: Moscow, Russia, 2017.

20. Zadeh, L.A. Fuzzy sets. Inf. Control 1966, 8, 338-353. [CrossRef]

21. Maslow, A.H. A Theory of Human Motivation. Psychol. Rev. 1943, 50, 370-396. [CrossRef]

22. Finkbeiner, M.; Schau, E.M.; Lehmann, A.; Traverso, M. Towards life cycle sustainability assessment. Sustainability 2010, 2, 3309-3322. [CrossRef]

23. Yang, J.; Zhang, F.; Jiang, X.; Sun, W. Strategic flexibility, green management, and firm competitiveness in an emerging economy. Technol. Forecast. Soc. Chang. 2015, 101, 347-356. [CrossRef]

24. Pociovălișteanu, D.M.; Novo-Corti, I.; Aceleanu, M.I.; Șerban, A.C.; Grecu, E. Employment Policies for a Green Economy at the European Union Level. Sustainability 2015, 7, 9231-9250. [CrossRef]

25. Duwe, S. Governing the Transition to a Green Economy Dis; Freie Universität Berlin: Berlin, Germany, 2015.

26. Jin, J.; Han, L. Assessment of Chinese green funds: Performance and industry allocation. J. Clean. Prod. 2018, 171, 1084-1093. [CrossRef]

27. Monasterolo, I.; Raberto, M. The EIRIN flow-of-funds behavioural model of green fiscal policies and green sovereign bonds. Ecol. Econ. 2018, 144, 228-243. [CrossRef]

28. Dulal, H.B.; Dulal, R.; Yadav, P.K. Delivering green economy in Asia: The role of fiscal instruments. Futures 2015, 73, 61-77. [CrossRef]

29. Durdyev, S.; Zavadskas, E.K.; Thurnell, D.; Banaitis, A.; Ihtiyar, A. Sustainable Construction Industry in Cambodia: Awareness, Drivers and Barriers. Sustainability 2018, 10, 392. [CrossRef]

30. Golubetskaya, N.P. Sustainable use of natural resources in the transition economy. In Bulletin Use and Protection of Natural Resources in Russia; NIA-Priroda: Moscow, Russia, 2004; Volume 5, pp. 23-34.

31. Porfiriev, B.N. Green economy: Global trends and prospects. Her. Russ. Acad. Sci. 2012, 82, 323.

32. Andreas, J.J.; Burns, C.; Touza, J. Renewable Energy as a Luxury. A Qualitative Comparative Analysis of the Role of the Economy in the EU's Renewable Energy Transitions During the 'Double Crisis'. Ecol. Econ. 2017, 142, 81-90. [CrossRef]

33. Kang, Z.Y.; Li, K.; Qu, J. The path of technological progress for China's low-carbon development: Evidence from three urban agglomerations. J. Clean. Prod. 2018, 178, 644-654. [CrossRef]

34. Newton, P. City transitions, infrastructure innovation, green economy and the eco-city. In Resilient Sustainable Cities: A Future; Pearson, L., Newton, P., Roberts, P., Eds.; Routledge: Abingdon, UK, 2014; Chapter 9; pp. 91-104.

35. Baranova, P.; Paterson, F. Environmental capabilities of small and medium sized enterprises: Towards transition to a low carbon economy in the East Midlands. Local Econ. 2017, 32, 835-853. [CrossRef]

36. Chen, C.; Lan, Q.; Gao, M.; Sun, Y. Green Total Factor Productivity Growth and Its Determinants in China's Industrial Economy. Sustainability 2018, 10, 1052. [CrossRef]

37. Stroebel, M. Tourism and the green economy: Inspiring or averting change. Third World Q. 2015, 36, 2225-2243. [CrossRef]

38. Nahman, A.; Mahumani, B.K.; De Lange, W.J. Beyond GDP: Towards a green economy index. Dev. S. Afr. 2016, 33, 215-233. [CrossRef]

(C) 2019 by the authors. Licensee MDPI, Basel, Switzerland. This article is an open access article distributed under the terms and conditions of the Creative Commons Attribution (CC BY) license (http://creativecommons.org/licenses/by/4.0/). 